Routledge Research in Early Modern History

Making the Union Work

Scotland, 1651-1763

Alexander Murdoch

Major-General Hezekiah Haynes and the Failure of Oliver Cromwell's

Godly Revolution, 1594-1704

David Farr

John Stearne's Confirmation and Discovery of Witchcraft

Text, Context and Afterlife

Scott Eaton

From Classical to Modern Republicanism

Reflections on England, Scotland, America, and France

Mark Hulliung

The Renaissance of Plotinus

The Soul and Human Nature in Marsilio Ficino's Commentary

on the Enneads

Anna Corrias

Voices in the Legal Archives in the French Colonial World

"The King is Listening"

Edited by Nancy Christie, Michael Gauvreau, and Matthew Gerber

The Political Discourse of the Polish-Lithuanian Commonwealth

Concepts and Ideas

Anna Grześkowiak-Krwawicz

The Polish-Lithuanian Commonwealth

History, Memory, Legacy

Edited by Andrzej Chwalba and Krzysztof Zamorski

For more information about this series, please visit: www.routledge.com/ Routledge-Reseatch-in-Early-Modern-History/book-series/RREMH

\section{The Polish-Lithuanian Commonwealth}

History, Memory, Legacy

\section{Edited by Andrzej Chwalba and Krzysztof Zamorski}

Routledge

Taylor \& Francis Group

NEW YORK AND LONDON 
First published 2021

by Routledge

52 Vanderbilt Avenue, New York, NY 10017

2 Park Square, Milton Park, Abingdon, Oxon, OX14 4RN

Routledge is an imprint of the Taylor \& Francis Group, an informa business

(C) 2021 Taylor \& Francis

The right of Andrzej Chwalba and Krzysztof Zamorski to

be identified as the authors of the editorial material, and of

the authors for their individual chapters, has been asserted in

accordance with sections 77 and 78 of the Copyright, Designs

and Patents Act 1988.

All rights reserved. No part of this book may be reprinted

or reproduced or utilised in any form or by any electronic,

mechanical, or other means, now known or hereafter invented,

including photocopying and recording, or in any information

storage or retrieval system, without permission in writing from

the publishers.

Trademark notice: Product or corporate names may be

trademarks or registered trademarks, and are used only for

identification and explanation without intent to infringe.

Library of Congress Cataloging-in-Publication Data

A catalog record for this book has been requested

ISBN. 978-0-367-42497-8 (hbk

ISBN: $978-0-367-85307-5$ (ebk)

Typeset in Sabon

by Apex Covantage, LLC

List of Illustrations

List of Contributors

viii

Introduction

ANDRZEJ CHWALBA AND KRZYSZTOF ZAMORSKI

1 The Polish-Lithuanian Commonwealth: History-

Legacy-Memory

ANTONY POLONSKY

PART I

The Beginnings of Poland-Lithuania

2 The Principles of Ancient Rzeczpospolita Formation: The Medieval Ruthenian Dimension

MYROSLAV VOLOSHCHUK

3 Words for Images: On Perceptions of 'Greek Manner' in Lithuania and Poland

GIEDRÉ MICKŨNAITÉ

4 Religious Tolerance and Intolerance in Vilnius in the Sixteenth and Seventeenth Centuries 
vi Contents

PART II

The Polish-Lithuanian Commonwealth

5 “A Free and Feudal Government": Civic Republican Mentalities in the Cities of the Polish-Lithuanian

Commonwealth

CURTIS G. MURPHY

6 Electing Kings With All Manner of Freedom:

The Polish-Lithuanian Elective Monarchy in Context

FELICIA ROŞU

7 Cases of the Expulsion of Jews From the Towns of the Grand Duchy of Lithuania: Strategies of the Burghers and the Jews

JURGITA ŠIAUČIUNAITĖ-VERBICKIENĖ

8 Tolerance as a Non-Topic: Cooperation on Behalf of the Town Between Catholics, Jews and Protestants in Early

Modern Rzeszów

YVONNE KLEINMANN

9 The Medical Science Heritage of French Physicians in Lithuania in the Last Quarter of the Eighteenth Century: Jean-Emmanuel Gilibert, Nicolas Regnier and

Jacques Briotet

ARNAUD PARENT

10 Discourses of Tolerance and Intolerance at the Four Years' Sejm (1788-1792)

RICHARD BUTTERWICK

\section{PART III}

Legacy and Memory of the Polish-Lithuanian

Commonwealth

11 The Frames of Reference of an Eighteenth-Century Jewish Galician Merchant (Based on the Writings of Dov Ber Birkenthal)
12 The Rights and Privileges of the Polish-Lithuanian Nobility: A Benchmark for the Russian Empire's Legislation of the Latter Half of the Eighteenth and Early Nineteenth Century?

TAMARA BAIRAŠAUSKAITÉ

13 France Facing the Independence of Poland: New Historiographical Approaches

FRÉDÉRIC DESSBERC

14 The French Position on the Polish Cause in 1918: Historical Borders and Principle of Nationalities

ISABELLE DAVION

15 The Polish-Lithuanian Commonwealth in the Politics of Memory in Belarus

LIUBOU KOZIK

16 Organizing the Past: The Policy of the Soviet Authorities Towards the Museums in Lviv, 1939-1941

IRYNA HORBAN

Index

GERSHON DAVID HUNDERT 


\section{Electing Kings With All Manner of Freedom}

\section{The Polish-Lithuanian Elective Monarchy in Context}

\section{Felicia Roşu}

\section{Introduction}

The Gentry of Poland make and defend their own Laws and Liberties, elect their King with all manner of Freedom, give him the Crown and Sceptre, appoint Ministers to counsel and instruct him, and their Number far exceeding that of the Senate, they easily keep the King and Senators in their Duty, and threaten both very often, especially in the Diet, where each Member has a Liberty to speak what he thinks, and to think what he pleases.

Despite the strong impression it made on outsiders, the elective principle was not unique to the Polish-Lithuanian Commonwealth. Quite the opposite: it was the predominant form of succession in northern and east-central Europe from the late Middle Ages to the seventeenth century. Sweden, Denmark, Bohemia, Hungary, and medieval Poland had all been elective systems. However, elective monarchy in early modern PolandLithuania was different from these earlier versions. First, it distanced itself from the dynastic principle that guided successions in most of Europe's elective monarchies. Elected kings could be related to their predecessors, but they did not have to be-in fact dynastic succession was regarded with suspicion by a large part of the Polish-Lithuanian electorate. Second, kingship was conditional. Both before and after their coronation, elected kings had to agree to a set of conditions that placed limitations on their power and included a disobedience clause: in case of abuse, the citizens of the Commonwealth could withdraw their allegiance to him. In Bodinian terms, this means that sovereignty was shared between king and estates. Third, voters in Poland-Lithuania were more numerous than elsewhere. Elections were open to all members of the nobility, and their decisions had to be based on consensus. Not everybody who had a right to vote showed up, but the thousands who did spent weeks arguing about the best candidate, following interregna that could last two years.

Nowhere else in early modern Europe-and arguably beyond, at least until the American Revolution-were royal elections conducted on 
this scale. Transylvania, however, provides an interesting comparison. The Transylvanian estates did not take constitutionalism as far as their Polish-Lithuanian counterparts, nor were they as successful in reigning in the autocratic tendencies of their princes, but on the point of "free elections" they were just as adamant as the Polish nobility. Although only hundreds of voters participated in Transylvanian elections and their degree of self-government was dented by Habsburg and Ottoman interference, other developments paralleled Polish-Lithuanian phenomena: the drastic weakening of the dynastic principle in the selection of rulers; the development of election conditions that had to be confirmed at their enthronement; and, perhaps most strikingly, the introduction of the right of disobedience among those conditions. Throughout its autonomous existence, which lasted between 1541 and 1711, Transylvania was in fact following the model of medieval Hungary, which may be considered an early influence in the Polish-Lithuanian case as well. ${ }^{2} \mathrm{My}$ paper analyzes the main characteristics of elective monarchy as illustrated by the Polish-Lithuanian Commonwealth while comparing and contrasting it with Transylvania and other early modern European polities.

\section{The Rise and Fall of Elective Monarchy} in Early Modern Europe

The impression that late medieval and early modern monarchies were predominantly hereditary, widely shared by university students today, is based on late seventeenth-century developments rather than earlier realities. The fact that the rising stars of the Ancien Régime-England, France, the Spanish and the Habsburg monarchies, and Muscovy-employed hereditary or dynastic principles in their successions has heavily contributed to this skewed image. ${ }^{3}$ The rest of the continent, however, had been using elective (or at any rate selective) methods of succession since the late Middle Ages and well into the early modern period. Elective monarchies were considered specifically "Germanic" or "Nordic" and made a strong impression on French constitutionalists and English Whigs, just as early Teutonic society did on Tacitus in the first century C.E. The examples of Denmark, Sweden, Hungary, and Poland were commonly discussed by both supporters and detractors of elective monarchy: François Hotman, Jean Bodin, and Robert Filmer are only a few examples of theorists engaged in the elective-versus-hereditary debate in the late sixteenth and early seventeenth centuries. ${ }^{4}$

Elective monarchies had special political arrangements-and the manner of electing kings in the Polish-Lithuanian Commonwealth was certainly unique-but the problems that such arrangements were trying to address were experienced across the continent. In the second half of the sixteenth century, many European monarchies faced similar challenges. The main problems that confronted them were the uncertainties of dynastic succession, increasing religious diversity, and the age-old rivalry between estates and rulers. Starting in the $1560 \mathrm{~s}$, the authority of the Habsburg monarch was shaken and then discarded in the Low Countries. Portugal went through a succession crisis in 1578-1580. England had an unmarried queen, which opened the possibility of arranging the next succession by election. In Scotland, George Buchanan claimed that the Scottish throne had always been elective in nature. In France, election was seriously considered from the 1570 s to the 1590 s - first by the Huguenots, who attempted to prove that the French throne had originally been elective, and then, after the assassination of Henry III, by members of the Catholic League. In 1576, the French debate on elective monarchy was important enough to make Jean Bodin feel the need to chastise those who publicly claimed that the French kings had received their power from the people. In 1581, he again attacked the proponents of the elective solution as "those who want to ruin well-ordered states and monarchies and to change the law of succession into elections, which is the inevitable ruin of monarchies." Between 1589 and 1593, the Catholic League actively supported the idea of elective monarchy, and the duke of Mayenne claimed to have the right to summon the Estates General to elect the king of France on the grounds that the dynastic family no longer had any eligible heirs. Henry IV's conversion to Catholicism put an end to the assembly, but Henry did negotiate directly with them about the terms of his conversion, therefore making his coronation the result of a process that may be deemed at least selective, if not elective. ${ }^{6}$ In short, elective monarchy was far from being an isolated oddity in sixteenthcentury Europe. It was on everybody's mind, even if it was not always put into practice.

In time, the elective principle faded from debates and it was gradually superseded by de facto or de jure dynastic options. Sweden and Denmark still had elective thrones in the 1500 s, but in practice they were already dominated by dynasties in the second balf of the century; they legally adopted the hereditary principle around the middle of the seventeenth century. The Holy Roman Empire, while formally an elective monarchy well into the modern period, became a Habsburg stronghold from the fifteenth century. The same happened with Bohemia and Hungary after 1526 . They nominally retained their elective thrones, but succession was kept within the Habsburg line; eventually they were turned into formal hereditary monarchies in the late seventeenth century. Transylvania followed the same model. In 1688, the Transylvanian estates yielded to Leopold I's pressures and agreed to abolish their right of election; two years later, the Diploma Leopoldinum of 1690 formally put Transylvania under Vienna's control while maintaining its separation from Hungary. In 1711, after two failed attempts by the estates to continue the practice of electing autonomous rulers under Ottoman suzerainty, Transylvania's princes were finally replaced by imperially appointed governors. 
To the east, the Romanian principalities had their own elective traditions, although they did not adopt constitutional solutions to regulate their successions. Their rulers had been traditionally elected by the country's top dignitaries in the late medieval period, but this form of succession was gradually combined with and eventually replaced by Ottoman appointments. In the eighteenth century, the Wallachian and Moldavian rulers were Greek subjects of the Porte, appointed directly by the Ottoman authorities.

In short, by the second half of the seventeenth century, there were drastically fewer elective monarchies in Europe than two centuries before: besides the papacy, and putting aside cases such as Venice, Genoa, and Lucca, which did not elect monarchic figures per se, the Polish-Lithuanian Commonwealth and (until 1711) Transylvania were the only political entities in Europe that neither did away with their rulers nor turned their thrones into dynastic holds or hereditary possessions.

\section{Fundamental Traits of Elective Monarchy}

Elective monarchies were not entirely unique: they shared a number of traits with other types of political arrangements in early modern Europe including hereditary monarchies. Common characteristics included the necessity of collaboration between rulers and estates and the evergrowing importance of the law in politics, both of which were long-term trends that had been present in many areas of the continent since the Middle Ages. However, the institutions set up in the sixteenth century in the Polish-Lithuanian Commonwealth (and in Transylvania to a certain extent) had a number of specific traits that set them apart from other monarchic systems-including earlier versions of elective monarchy. Their most obvious peculiarity was the form of succession to the throne, although election alone does not fully explicate the mechanism at play in these "upgraded" versions of elective monarchy. There are additional aspects to consider when it comes to royal or princely elections: first, the presence and length of interregna, or the formal procedure of authority transfers; second, eligibility criteria, or how wide the pool of acceptable candidates was; third, the size of the electorate, or how many voters participated in elections; fourth, election procedures, or the voting rules employed at elections; and fifth, the conditional nature of rulership. The following sections analyze these aspects and evaluate the degree to which they differed from other political systems.

\section{Interregna}

Perhaps more than the formal election of rulers, the presence of interregna was a fundamental aspect of elective monarchy. Neither in the Commonwealth, nor in Transylvania, nor indeed in the Holy Roman
Empire or other elective monarchies such as Hungary, Bohemia, or Sweden was the transfer of authority from king to king automatic, but it passed through the hands of the estates, who had to offer some expression of consent before or during the new king's coronation, either by acclamation or by actual voting. That process was supposed to take place in the space between the death (or deposition) of one ruler and the enthronement of the next; a period of royal vacancy was expected, even if it was not always made constitutionally explicit. ${ }^{8}$ This manner of succession contrasted strikingly with that practiced in France from the sixteenth century onward, where theorists argued that "the king never dies" in order to show that ultimate authority remained with a royal person (and not just an abstract crown) at all times, and that it never had to revert to other members of the body politic for the period between a king's death and the next one's coronation. In short, interregna were not permitted in France. True, not everybody agreed - in 1579, a famous treatise claimed that it was the people, not the king, who never died. But the events of the 1590 s turned the scale in favour of a purer hereditary principle than had been applied before. By the seventeenth century, the idea behind "Le roi est mort! Vive le roi!" managed to completely push aside earlier notions that the consent of the people was required for the French investiture. The act of coronation lost some of its inaugural character, being reduced to a ritual confirmation of the dynastic right to rule, rather than the moment marking the beginning of a reign. ${ }^{9}$

In contrast, the idea that "the king dies, but the crown does not" with the crown signifying the respublica, the political community-won the day in the Polish kingdom and later in the Polish-Lithuanian Commonwealth. ${ }^{10}$ It did so to such an extent that a temporal separation between the death of one king and the coronation of the next was not only expected but became obligatory in 1530 , and most famously in the Henrician articles from 1573 onward. Interregna lasted between one and two years, and elections vivente rege (during the lifetime of the incumbent king) were forbidden, in order to lessen the danger of royal influence in the process. During interregna, authority devolved to the kingless parliament (sejm), which functioned as an emergency confederation and had constitutive powers in the sense that it negotiated the contract with the new king, even though its decisions would only become public law with royal confirmation.

Transylvania too had interregna, although they only lasted weeksthe estates feared that the Habsburgs or the Ottomans would attempt to appoint their ruler and usually rushed through the process in order to preserve their right of election. ${ }^{11}$ Moreover, the Transylvanians permitted elections vivente principe (and therefore the elimination of interregna) six times during the elective period, usually as a consequence of pressures by the incumbent ruler, although concern for the instability of interregna was the reason that was publicly proclaimed. ${ }^{12}$ Still, only 
three of the rulers elected in this manner governed effectively; in the other three cases, the estates elected other successors after the death of the incumbent. Furthermore, after 1599, at each election vivente principe a disobedience clause was added to the electoral conditions of the successor, claiming that the estates could withdraw their allegiance in cases of abuse of power. The threat of resistance and deposition was meant as a counterweight to the growing power of rulers during long and stable reigns. It was a way of reminding them that, no matter how successful they might be in dominating the estates in day-to-day politics, succession was not automatic but depended on the estates. ${ }^{13}$

\section{Eligibility Criteria}

The relatively high number of eligible successors without necessary relation to the incumbent ruler or any royal house was one of the most impressive characteristics of elective monarchy in the Polish-Lithuanian Commonwealth. Nevertheless, neither the number of candidates nor their lack of relation to the incumbent are precise identification tools for elective monarchy as a form of government. The Holy Roman Empire was an elective monarchy even though the eligible candidates had been limited to the members of the House of Habsburg since the fifteenth century; similarly, an election with only one publicly nominated candidate (as was technically the case in Transylvania in 1571, when Stephen Báthory was elected voivode of Transylvania) was still an election. As a rule, the pool of possible successors was widest when foreign candidates were considered eligible, as was the case in Poland-Lithuania (but not in Transylvania). In the Commonwealth, there could be dozens of potential candidates at each election (in 1573 there were more than twenty native candidates at one point), but the realistic options, which only became clear towards the end of each interregnum, would usually hover around five or six candidates in more open elections, and one or two candidates in less competitive successions such as those that took place after the first two Vasa kings (1632 and 1648). ${ }^{14}$ But what truly mattered was not so much the number of candidates as the fact that they were not elected on the basis of their family connections to the previous king. Even though sons of kings (or princes) were occasionally elected, in such situations the voters insisted that they were elected regardless of, not because of their blood relations. To show the importance of the matter, the usage of the term "heir" was forbidden in the Henrician articles-it was by the principle of election, not that of heredity, that succession was determined. ${ }^{15}$

The Transylvanian constitutions did not mention heredity, but the matter was treated as in the Polish-Lithuanian Commonwealth: relatives of previous rulers could be elected, but they did not have to be. Instead, the right of free election was underlined. When the minor Sigismund Báthory became the successor of his father in 1581 (a few days before the latter's death), the resolution of the Transylvanian estates made sure to state that the choice had been made "with good reason and by free election" (certis et solidis rationibus ac libero suffragio), as if to deny that the estates had succumbed to any pressure from the incumbent ruler. ${ }^{16}$ Even when the system was abused by autocratic tendencies, outside interference, or internal strife, the Transylvanian estates insisted on performing-and recording - the ritual act of election, which they meant to transmit to future generations whole and untainted. It was not the abuses that they chose to put in the public record for posterity, but the act of "free" election, so that no dangerous precedent may be set for the future. In that, they were fundamentally similar to the Polish-Lithuanian nobility, who valued free elections - and their transmission to future generationsabove every other liberty.

\section{Size of Electorate}

The Polish-Lithuanian Commonwealth (and, at some distance behind, Transylvania) had the highest number of electors in early modern Europe. The Holy Roman emperor was elected by seven electors, the Danish king by approximately twenty councilmen, the Venetian doge by forty-one electors, and the pope by about seventy cardinals. Transylvanian rulers were elected by assemblies consisting of one to three hundred estate delegates. ${ }^{17}$ In contrast, for the first hundred years of the PolishLithuanian elective system, the number of voters who attended election sejms varied between 3,400 and 20,000 . The first three elections (1573, 1575 , and 1587) are estimated to have been attended by 6,000 to 20,000 people, although the highest estimates for the second and third election $(12,000$ and 20,000 respectively) probably err on the side of exaggeration. Attendance lists are available from 1632 onward, so historians can more easily calculate the number of voters who were present at later elections. In $1632,1648,1669$, and 1674 , there were between 3,450 and 4,352 recorded voters, while at the 1669 election their number rose to $11,271 .^{18}$ Even if we only took the conservative estimates into account, the Polish-Lithuanian electorate was by far the most numerous in early modern Europe.

\section{Voting Procedures}

How did thousands of men manage to pick the same candidate? There was only one way: through endless debate and negotiation. Decisions were supposed to be consensual, which means that voting was-and had to be-a public and collective affair. The final decision would only be reached after several rounds of voting, during which those present were not just allowed but expected to change their minds. Consensual decisionmaking required flexibility. Definitive choices made before the election, 
which is how we tend to think about elections today-we make our decisions at home, then go into a booth and exercise our most fundamental political right in secret, i.e. in private-invalidated the system because it excluded negotiation and compromise. This incongruity is illustrated by several instances of double or divided elections, when rival parties preferred to stick to their previously made decisions rather than agree to compromise, resulting in two candidates being proclaimed at the same time. In a system where political choice was meant to be the result of collective negotiation, double elections were a disfunction: they happened when the voters did not play by the rules. The rules, however, remained unchanged until the end of elective monarchy in Poland-Lithuania, reflecting an ideal that was not always upheld but which remained central to the Polish-Lithuanian understanding of how the political community was supposed to function. That is why, for all the admiration that the Poles had for Venice, the secret ballot never took hold in the Commonwealth: it was based on a fundamentally different vision of politics. ${ }^{19}$

To be fair, consensus was perceived as the ideal way of making decisions not just in Poland-Lithuania but throughout the continent, but by the sixteenth century most elective systems operated on the much more pragmatic principle of the majority rule. It was first implemented at papal elections in the twelfth century. In the Holy Roman Empire, four out of seven electors were sufficient for a binding decision. In Transylvania, at regular estate assemblies, voting was done by estate and by majority rule (two out of three estates had to agree), but at elections the logic of consensus still reigned: there was no formal counting of votes and general debates were followed by acclamation as soon as one dominant opinion reached critical mass.

The same logic was applied at Polish-Lithuanian elections, although there was a difference between how the senators and the szlachta voted. The senators' votes were presented, counted, and recorded individually, whereas those of the nobility came closer to the Transylvanian method: preferences were first determined within palatinates (by using a variety of methods, from majority voting, to debates by representatives, to acclamation), then speakers assessed the dominant opinions among palatinates and tried to create consensus by convincing everybody to accept the opinions of the majority. Since they involved many more participants, the Polish-Lithuanian electoral negotiations were more complex and lasted longer than the Transylvanian ones (weeks, instead of hours or days), but in both places the importance of consensus and the danger of dissent were perceived in a similar light. Collective choices were considered legitimate only if nobody disagreed-a condition that is often confused in modern scholarship with the unanimity rule, although it functioned in practice as a closeted majority rule: the way it worked was through the majority imposing its opinions on a dissenting minority. The fundamental difference with the majority rule is that election by consensus ften involved extended negotiations with the dissenting parties-as happened at the election of Henry Valois in 1573, when the dissenters demanded and eventually obtained the inclusion of the Warsaw Confederation, guaranteeing religious peace, in the Henrician articles. Debates (and at times conflict) continued until everybody accepted the majority's choice and dissent was no longer publicly expressed. That, in a nutshell, was the meaning of the nemine contradicente ("with nobody's dissent") principle, the precursor of the liberum veto that disrupted so many sejms from 1652 onwards. It was much more effective at election sejms than at regular sejms for the simple reason that election sejms could not afford to end without resolution: a king had to be chosen eventually. Therefore, at elections, disagreement continued to function as a means to force negotiation, rather than an instrument of sabotage, as happened at regular sejms from the seventeenth century. Even though there were cases of serious disagreement and even military clashes on account of divided elections, the principle of consensual decisions remained a fundamental part of Poland-Lithuania's elective system, despite several attempts to introduce the majority rule. ${ }^{20}$ Until the end of the Commonwealth's existence, a significant part of the electorate perceived consensus as more important than efficiency - which is arguably a difference of essence, rather than degree, from the developments taking place in the rest of Europe in the early modern period.

\section{Conditional Rulership}

Another fundamental characteristic of elective monarchy in Transylvania and Poland-Lithuania was that election was in principle for life, but not unconditional. The conditions that Transylvanian and Polish-Lithuanian rulers had to confirm at their enthronement were not unique in their nature; virtually all early modern rulers made promises at their inauguration in the form of coronation oaths. What set them apart was their degree of specificity and the fact that, in both countries, they included guarantees for the right of election, religious pluralism (or an interdiction of religious persecution), and the possibility of disobedience in cases of abuse. The latter was probably the most spectacular trait of elective monarchy in east-central Europe, and it led Jean Bodin to argue that the Polish-Lithuanian monarch was only a president with no real sovereignty on account of the fact that he could be "punished" (i.e. deposed) by the estates. ${ }^{21}$ Most importantly, the disobedience clause was not an empty threat. It was put in practice several times-either as negotiation tool or as justification for the deposition of a ruler-in both Transylvania and Poland-Lithuania. ${ }^{22}$

But conditional rulership and the right of disobedience were not unique to Transylvania and the Commonwealth-nor to elective systems, for that matter. Neither England nor Brabant were elective monarchies, yet 
they had the Magna Carta and the Joyous Entries. From 1222 to 1687, Hungary also had a disobedience clause among the articles confirmed by its kings, which were in fact the source of inspiration for Transylvania's own electoral conditions (and arguably for Poland-Lithuania's as well), but its elective system was weaker on account of its having been turned into a formality by the Habsburgs after 1526 and more decisively in 1647 and 1687 , when the estates were forced to turn their throne into a Habsburg hereditary possession. In short, the Henrician articles and the Transylvanian electoral conditions differed from other European instances of conditional rulership by a matter of degree, rather than essence. However, that degree was by no means negligible. The disobedience clause strengthened the conditional character of rulership in elective monarchies, while non-dynastic succession lent more substance to the disobedience clause, making the combination of the two a peculiarly strong instance of early modern republicanism and constitutionalism.

\section{Conclusions}

No other early modern polity organized elections on the scale of the Polish-Lithuanian Commonwealth. More people, more time, and more explicit regulations were involved in its elections than in those of any other country. Seen in this light, the Commonwealth may appear as a north-eastern European sonderweg. Yet the Polish-Lithuanian version of elective monarchy was not a unique invention, but rather a particularly strong manifestation of republican and constitutionalist trends that also affected many other parts of late medieval and early modern Europe. The most striking elements that characterized it-non-dynastic succession and conditional rulership-could also be found elsewhere, albeit in weaker versions: Transylvania and Hungary; Bohemia, Sweden, and Denmark; and even some hereditary monarchies such as medieval England. But even if the traits of the Polish-Lithuanian elective system, taken separately, differed from the rest of Europe more by degree than essence, there is no question that the combination of all its traits put together resulted in a remarkable package that cannot be found elsewhere as such.

The initial impetus for the establishment of elective monarchy was to avoid the deep disturbances that usually accompanied the extinction and replacement of royal families. In the process, however, the estates seized the opportunity to reexamine and reform the fundamental principles of their political community, a situation that gave them great influence and in which they chose to engage regularly rather than solely in situations of dynastic crisis. In this manner, what used to be irregular successions marking the end of a dynasty turned into regular occurrences marking the end of each reign. Elections were not simply the process of identifying the next ruler, but also intense political deliberations about the source and nature of the highest authority in the realm, especially in the founding decades of each elective system (in the 1570s-1580s in the Commonwealth, and in the 1570 s and $1610 \mathrm{~s}-1630 \mathrm{~s}$ in Transylvania). In a sense, they were constitutionally regulated revolutions-if by revolution we mean, on the one hand, an overhaul of government, and on the other hand, the revaluation and reaffirmation of a polity's fundamental principles. In Poland-Lithuania's case, these fundamental principles were represented by the Lublin Union of 1569 and the Henrician articles of 1573; in Transylvania, by each ruler's conditions of election, whose recurrent features included the protection of religious peace and the right of free election.

As revolutions go, the ones occasioned by the elections of rulers were relatively peaceful, despite the political instability they brought and the occasional violence they triggered. In Poland-Lithuania, upheaval was particularly noticeable at times of divided elections $(1575,1587,1733)$ and anti-monarchic movements (1606-1609, 1665-1666), while Transylvania had its own measure of disorders, exacerbated by Ottoman and Habsburg interference in elections. Yet the disturbances experienced at those times were comparatively smaller than the civil wars experienced in western Europe at times of troubled successions. Theorists such as Bodin and Filmer often decried elections for their instability-as would indeed anti-democratic politicians today - but I would argue that the type of turmoil occasioned by a (functional) elective system was less dangerous and more empowering for the members of the body politic than the severe disruptions occasioned by the extinction of a royal family in dynastic monarchies. Ironically, the greatest strength of elective monarchiesi.e. the fact that they contained constitutional outlets for the tensions between rulers and estates-was also their greatest weakness, since it occasioned outside interference and ultimately the demise of the political community as a whole. One by one, the elective systems of early modern Europe were eliminated by their own rulers or by outside forces; both Transylvania and Poland-Lithuania succumbed to the latter scenario. At the end of the eighteenth century, the only place where a political system akin to elective monarchy was being considered anew-and where the Polish-Lithuanian model was seen as a cautionary tale-was the United States of America, where the place of the monarch was eventually taken by the president. ${ }^{23}$

The current struggle taking place in Europe and North America over the role and meaning of government, as well as the extent of its power, has the same nature as the strife to define the function and authority of rulers in early modern Europe. The constant vacillation in the United States between republican and more liberal visions of politics is, for all intents and purposes, the modern version of the centuries-old tension between political liberty and personal security, self-government and efficient government, the desire for greatness and the concern for fairness, private interest and the public good. However, unlike the citizens 
of the early modern world, today's citizens leave much of this debate to politicians, who play the role of expert-citizens, as it were. Voting for president - one of the few political prerogatives still regularly exercised by citizens, particularly in Europe-is certainly more orderly and less disruptive than voting for king used to be in Poland-Lithuania. Yet for this reason, elections today rarely force voters to reexamine, reestablish, and reaffirm the bases of their polities to the extent that they did in the early modern period. When that happens, the disruption is seen as a crisis, instead of what it is: the very stuff of politics.

\section{Notes}

1. Bernard Connor, The History of Poland in Several Letters to Persons of Quality Giving an Account of the Ancient and Present State of That Kingdom (London: Printed by J.D. for Dan Brown . . . and A. Roper . . ., 1698) 2:175.

2. Martyn C. Rady, "Hungary and the Golden Bull of 1222," Banatica 24, no. 2 (2014); 87-108; Felicia Roşu, "Free from Obedience: Constitutiona Expressions of the Right of Resistance in Early Modern Transylvania and Poland-Lithuania," European History Quarterly 47, no. 1 (2017): 19.

3. In fact, from a legal point of view, few monarchies were truly hereditary. Jurists such as Jean Bodin insisted on using public law and not heredity (the latter being a notion that belonged to the private, not the public realm) in their justification of succession rules: "divine" law, customary law, the fictitious French "Salic" law, "fundamental" law, etc. That was why the Paris parlement annulled Louis XIV's will (1715), in which he had attempted to grant the right of succession to his bastard sons. In contrast, Peter the Great was allowed to abolish primogeniture and leave the appointment of successors entirely in the hands of incumbent rulers, which effectively turned the Russian state into their private property. See Ralph E. Giesey, "The Juristic Basis of Dynastic Right to the French Throne," Transactions of the American Philosophical Society 51, no. 5 (1961): 3-47; Jean Bodin, Les six livres de la république, ed. Christiane Frémont, Marie-Dominique Couzinet, and HenriMarie Rochais (Paris: Classiques Garnier 1986) bk 1, chap. 8, p. 227; DanGovernment," Political Theory 41, no. 3 (2013): 409-440. Jeroen Duindam, Dynasties: A Global History of Power, 1300-1800 (Cambridge: Cambridge University Press, 2015), 143-145; Russell E. Martin, "Law, Succession, and the Eighteenth-Century Refounding of the Romanov Dynasty," in Dubi tando: Studies in History and Culture in Honor of Donald Ostrowski ed. Brian J. Boeck, Russell E. Martin, and Daniel Rowland (Bloomington: Slavica Publishers, 2012), 225-242.

4. See a short but insightful comment on this debate in Earl R. Wasserman, "The Meaning of 'Poland' in The Medal," Modern Language Notes 73, no. 3 (March 1958): 165-167.

5. Jean Bodin, "Apologie de Rene Herpin pour la Republique," in Les six livres de la république, vol. 6, ed. Christiane Frémont, Marie-Dominique Couzinet, and Henri-Marie Rochais (Paris: Classiques Garnier, 1986), 313-409, 319; and Bodin, Les six litres, bk. 6, chap. 5, 213. For the elective solution in late sixteenth-century England, see Dorota Pietrzyk-Reeves, Ead rzeczypospolitej: Polska myśl polityczna XVI wieku a klasyczna tradycja republikanska (Cracow: Ksiegarnia Akademicka, 2013), 404-406; Howard Nenner, The Right to Be King: The Succession to the Crown of England, 1603-1714 (Chapel Hill, NC: The University of North Carolina Press, 1995), 1-6. See also Sarah Hanley, "The French Constitution Revised: Representative Assemblies and Resistance Right in the Sixteenth Century, ${ }^{\text {" }}$ in Society of Institutions in Early Modern France, ed. Mack P. Holt (Athens and London: University of Georgia Press, 1991), 36-50; J. Russell Major, Representative Government in Early Modern France (New Haven, CT: Yale University Press, 1980), 182-187; Julian H. Franklin, ed., Constitutionalism and Resistance in the Sixteenth Century: Three Treatises by Hotman, Beza, Mornay (New York: Pegasus, 1969).

6. See James B. Collins, The State in Early Modern France, 2nd ed. (Cambridge: Cambridge University Press, 2009), 1-2; Mark Greengrass, France in the Age of Henry IV: The Struggle for Stability, 2nd ed. (New York: Routledge, 2013), 70-72.

7. Some authors argue that other ecclesiastical territories, such as certain bishoprics and archbishoprics in the Holy Roman Empire (the Germania Sacra) were also "elective monarchies" in a lax sense of the term. See, for example, Robert W. Scheller, "Art of the State: Forms of Government and Their Effect Robert W. Scheller, "Art of the State: Forms of Government and Their Effect
on the Collecting of Art 1550-1800," Simiolus: Netherlands Quarterly for the History of Art 24, no. 2/3 (1996): 275-286, 278.

8. For pre-1544 Sweden, see Corinne Péneau, "La succession royale dans le royaume de Suède, entre coutume héréditaire et loi élective (XIIIe-XIVe siècles)," in Making and Breaking the Rules: Succession in Medieval Europe, c. 1000-c.1600. Établir et abolir les normes: la succession dans l'Europe c. 100 édiévale, vers $1000-v e r s$ 1600., ed. Frédérique Lachaud and Michael A. médiévale, vers 1000-vers 1600 ., ed. Frédérique
Penman (Turnhout: Brepols Publishers, 2008), 34.

9. Ralph E. Giesey, "Inaugural Aspects of French Royal Ceremonials," in Coronations: Medicval and Early Modern Monarchic Ritual, ed. János M. Bak (Berkeley: University of California Press, 1990), 36-40; Richard A. Jackson, "Elective Kingship and Consensus Populi in Sixteenth-Century France," The Journal of Modern History 44, no. 2 (June 1972): 161-162, 165; Bodin, Les six livres, bk. 1, chap. 8, 227; bk. 6, chap. 5, p. 213. For the origins of "the king never dies" formula, see Ernst Kantorowicz, The King's Two Bodies (Princeton: Princeton University Press, 1985), 383ff.

10. Marcin Bielski, Kronika (1597) (Sanok: nakl. i druk Karola Pollaka, 1856) $2: 1207$. See also the distinction between loyalty to the crown and loyalty to the king made during the Sandomierz rokosz (1606) in Kate Wilson, "The Jewel of Liberty Stolen? The Rokosz of Sandomierz and Polish Dissent" (Oxford, 2002), 2, http://users.ox.ac.uk/ oaces/conference/papers/Kate_Wil son.pdf. The equivalence between crown and the political community was also strong in Hungary; see László Péter, "The Holy Crown of Hungary, Visible and Invisible," The Slavonic and East European Review 81, no. 3 (2003): 421-510.

11. Graeme Murdock accounts this situation for the Transylvanian estates" greater "political discipline." See Graeme Murdock, "Freely Elected in Fear': Princely Elections and Political Power in Early Modern Transylvania," Journal of Early Modern History 7, no. 3/4 (2003): 243-244.

12. See, for example, the articles issued by the Transylvanian estates in 1581 at the election of the nine-year-old Sigismund Bathory as successor to his father in Sándor Szilágyi, ed., Erdélyi Országgüilési Emlékck (Budapest: Magyar Tudományos Akadémia Könyvkiadó Hivatala, 1876-1898), 3:157-158. 13. Roşu, "Free from Obedience," 23. 
14. Girolamo Lippomano, "Relazione (1575)," in Le relazioni degli ambasciatori venti al senato durante il secolo decimosesto, vol. 6 , ed. Eugenio Albèri (Florence. Società editrice fiorentina 1862) 297, 299. Swiętoslaw Orzelski, Interregai Poloniae libros 1572-1576, ed. Ed cow: Nakładem Akademii Umiejętności, 1917), 105-108; Jan Dzięgielewski, Sejmy Elekcyjne, Elektorzy, Elekcje 1573-1674 (Pultusk: Wyższa szkoła humanistyczna im. Aleksandra Gieysztora w Pułtusku, 2003).

15. Stanislaw Grodziski, Irena Dwornicka, and Waclaw Uruszczak, eds., Volumina Constitutionum (Warsaw: Wydawnictwo Sejmowe, 1996_2005), $2 / 1: 326$.

16. Szilágyi, Erdélyi Országgülési Emlékek, 3:158.

17. For the 1571 Transylvanian election, see Roşu, Elective Monarchy, 97-98.

18. Dzieggielewski, Sejmy Elekcyine, Elektorzy, Elekcje, 70-74. See also Ewa Dubas-Urwanowicz, Koronne zjazdy szlacheckie: $w$ dwóch pierwszych bezkróletwiach po śmierci Zygmunta Augusta (Bialystok: Wydawnictwo Uniwersytetu w Białymstoku, 1998), 269, 293; Michał Kopczyński and Jakub Brodacki, "Obywatele czy tlum? Elektorzy wladców Rzeczypospolitej z województwa mazowieckiego w latach 1632-1764," Przeglad Historyczny 106, no. 1 (2015): 128.

19. Orzelski, Interregni, 390; Stanislaw Konarski and Zdzislaw Kaczmarczyk, eds., Volumina Legum: przedruk zbioru praw staraniem XX. Pijarótw $w$ Warszawie od roku 1732 do roku 1782 wydanego, 8 vols. (Petersburg: Ohryzko Jozafat, 1859-60), 2:241.

20. Rosu, Elective Monarchy, 97-129.

21. Bodin, Les six livres, bk. 2, chap. 3, 48-49.

22. Roşu, "Free from Obedience," 21, 24-25.

23. See, for example, Thomas Jefferson to James Madison, Paris, 20 December 1787, in "The Letters of Thomas Jefferson 1743-1826," American History from Revolution to Reconstruction and Beyond, www.let.rug.nV usa/presidents/thomas-jefferson/letters-of-thomas-jefferson/ (date of access 19.08 2014): Max Farrand ed. The Records of the Federal Convention of 1787 (New Haven, CT: Yale University Press, 1911), 1:234; 3:288; Quentin Skinner, Liberty Before Liberalism (Cambridge: Cambridge University Press, 1998), 35-36.

\section{Bibliography}

Bodin, Jean, "Apologie de Rene Herpin pour la Republique." In Les six livres de la république, edited by Christiane Frémont, Marie-Dominique Couzinet, and Henri-Marie Rochais. Paris: Classiques Garnier, 1986.

Bodin, Jean, Les six livres de la république. Edited by Christiane Frémont, MarieDominique Couzinet, and Henri-Marie Rochais. Paris: Classiques Garnier, 1986.

Collins, James B., The State in Early Modern France, 2nd ed. Cambridge: Cambridge University Press, 2009.

Connor, Bernard, The History of Poland in Several Letters to Persons of Quality Giving an Accotht of the Ancient and Present State of That Kingdom. London: Printed by J.D. for Dan Brown ... . and A. Roper ..., 1698.

Dubas-Urwanowicz, Ewa, Koronne zjazdy szlacheckie: $w$ dwóch pierwszych bezkrólewiach po śmierci Zygmunta Augusta. Bialystok: Wydawnictwo Uniwersytetu w Bialymstoku, 1998.
Duindam, Jeroen, Dynasties: A Global History of Power, 1300-1800. Cambridge: Cambridge University Press, 2015.

Dzięgielewski, Jan, Sejmy Elekcyine, Elektorzy, Elekcje 1573-1674. Pultusk: Wyższa szkoła humanistyczna im. Aleksandra Gieysztora w Pultusku, 2003.

Farrand, Max, ed., The Records of the Federal Convention of 1787. New Haven, CT: Yale University Press, 1911.

Franklin, Julian H., ed., Constitutionalism and Resistance in the Sixteenth Century: Three Treatises by Hotman, Beza, Mornay. New York: Pegasus, 1969. Giesey, Ralph E., "Inaugural Aspects of French Royal Ceremonials." In Coronations: Medieval and Early Modern Monarchic Ritual, edited by János M. Bak, 35-45. Berkeley: University of California Press, 1990.

Giesey, Ralph E., "The Juristic Basis of Dynastic Right to the French Throne." Transactions of the American Philosopbical Society 51, no. 5 (1961): 3-47.

Greengrass, Mark, France in the Age of Henry IV: The Struggle for Stability, 2nd ed. New York: Routledge, 2013.

Grodziski, Stanisław, Irena Dwornicka, and Waclaw Uruszczak, eds., Volumina Constitutionum. Warsaw: Wydawnictwo Sejmowe, 1996-2005.

Hanley, Sarah, "The French Constitution Revised: Representative Assemblies and Resistance Right in the Sixteenth Century." In Society of Institutions in Early Modern France, edited by Mack P. Holt, 36-50. Athens and London: University of Georgia Press, 1991.

Jackson, Richard A., "Elective Kingship and Consensus Populi in Sixteenth-Century France." The Journal of Modern History 44, no. 2 (June 1972): 155-171.

Kantorowicz, Ernst, The King's Two Bodies. Princeton: Princeton University Press, 1985.

Konarski, Stanisław, and Zdzislaw Kaczmarczyk, eds., Volumina Legtum: przedruk zbioru praw staraniem XX. Pijarów w Warszawie od roku 17.32 do roku 1782 wydanego, 8 vols. Petersburg: Ohryzko Jozafat, 1859-60.

Kopczyński, Michał and Jakub Brodacki, "Obywatele' czy thum? Elektorzy wladców Rzeczypospolitej $z$ województwa mazowieckiego w latach 1632 1764." Przeglad Historyczny 106, no. 1 (2015): 119-137.

Lee, Daniel, "Office Is a Thing Borrowed: Jean Bodin on Offices and Seigneurial Government." Political Theory 41, no. 3 (2013): 409-440.

"The Letters of Thomas Jefferson 1743-1826." American History from Revolution to Reconstruction and Beyond, www.let.rug.nl/usa/presidents/thomasjefferson/letters-of-thomas-iefferson/ (accessed 19.08.2014).

Lippomano, Girolamo, "Relazione (1575)." In Le relazioni degli ambasctatori veneti al senato durante il secolo decimosesto, vol. 6., edited by Eugenio Albèri, 271-316. Florence: Società editrice fiorentina, 1862.

Major, J. Russell, Representative Government in Early Modern France. New Haven, CT: Yale University Press, 1980.

Martin, Russell E., "Law, Succession, and the Eighteenth-Century Refounding of the Romanov Dynasty." In Dubitando: Studies in History and Culture in Honor of Donald Ostrowski, edited by Brian J. Boeck, Russell E. Martin, and Daniel Rowland, 225-242. Bloomington: Slavica Publishers, 2012.

Murdock, Graeme, "'Freely Elected in Fear': Princely Elections and Political Power in Early Modern Transylvania." Journal of Early Modern History 7 no. $3 / 4$ (2003): 213-244. 
194 Felicia Roşu

Nenner, Howard, The Right to Be King: The Succession to the Crown of England, 1603-1714. Chapel Hill, NC: The University of North Carolina Press, 1995.

Orzelski, Świętoslaw, Interregni Poloniae libros 1572-1576. Edited by Edward Kuntze. Cracow: Nakładem Akademii Umiejętności, 1917.

Péneau, Corinne, "La succession royale dans le royaume de Suède, entre coutume héréditaire et loi élective (XIIIe-XIVe siècles)." In Making and Breaking the Rules: Succession in Medieval Europe, c. 1000-c.1600. Etablir et abolir les normes: la succession dans l'Europe médiévale, vers 1000-vers 1600 ., edited by Frédérique Lachaud and Michael A. Penman. Turnhout: Brepols Publishers, 2008.

Péter, László, "The Holy Crown of Hungary, Visible and Invisible." The Slavonic and East European Review 81, no. 3 (2003): 421-510.

Pietrzyk-Reeves, Dorota, tad rzeczypospolitej: Polska myśl polityczna XVI wieku a klasyczna tradycja republikaniska. Cracow: Ksiegarnia Akademicka, 2013.

Quentin Skinner, Liberty Before Liberalism. Cambridge: Cambridge University Press, 1998.

Rady, Martyn C., "Hungary and the Golden Bull of 1222." Banatica 24, no. 2 (2014): 87-108.

Rosu, Felicia, "Free from Obedience: Constitutional Expressions of the Right of Resistance in Early Modern Transylvania and Poland-Lithuania," European History Quarterly 47, no. 1 (2017): 6-31.

Scheller, Robert W., "Art of the State: Forms of Government and Their Effect on the Collecting of Art 1550-1800." Simiolus: Netherlands Quarterly for the History of Art 24, no. 2/3 (1996): 275-286.

Szilágyi, Sándot, ed., Erdélyi Országguïlési Emlékek. Budapest: Magyar Tudományos Akadémia Könyvkiadó Hivatala, 1876-1898.

Wasserman, Earl R., "The Meaning of 'Poland' in The Medal." Modern Language Notes 73, no. 3 (March 1958): 165-167.

Wilson, Kate, "The Jewel of Liberty Stolen? The Rokosz of Sandomierz and Polish Dissent." Oxford, 2002, 2, http://users.ox.ac.uk/ oaces/conference/papers/ Kate_Wilson.pdf 